\title{
雌牛の繁殖障害のホルモン療法
}

高嶺—浩*

性ホルモン剤は近年各種の製剤が市販されるようにな ったので，その応用範团が桩まり治療效果炕をみるべき ものがあるが，一面使用すべきホルモンの種類, 適用の 量怙よび時期の選択が複雑となり，その便用に適正を欠 く向きが少くないよらである.

本稿は雌牛の繁殖障害, 殊飞卵栄疾患汶対するホルモ ン治療理論について解説する。

\section{I - 基本となる考え方}

\section{1. 要 項}

性ホルモン剤の使用汇適正を期すとは，まずつぎのこ とがらをよくわきす党なくてはならない。

（1）性機能のホルモン支配についての正しい知識をも つこと.

（2）性ホルモン剤の生理作用の特徴を理解すること.

(3) 対象牛の病性について，機能上の失宜を判定する 臨床的な診断にもとづき，理論的に適用すべき製剤の種 類と，量と時期を割出してその応用を図ること。

(4) - 站象牛が適用剤似反応し施用效果が上る上了生体 の感受性を整えること.

\section{2. 基礎知識}

性ホルモン呿よびその生理作用に関する基礎知識につ いては，本会誌をはじめ関係雑誌あるいは近刊の諸講 座，成書なぞと記載のあることであり，紙面の都合もあ って簡略にするが，注意を喚起したいことは，この分野 そ拈ける知見は日々新たであるといっても過言ではない 位で，絶壳ず新知識の吸収を図らなければ，十年一日の ごとき知識ではついて行けないことが多いということで ある. 反面注複雑なホルモン支配機構については，ま だ究明されていない点が多く残されているとい光るわけ で, 従って性ホルモン剤の使用法沉ついても確固たる方 法が決定しているとはいいきれない。

\section{3. 形態検査と機能検査}

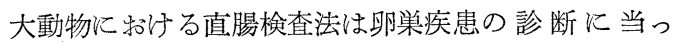
て，卓越した方法であることは論を侔たない，卵巣の発 育不全, 休止, 萎縮, 囊腫, 黄体遺残など多くの卵巣疾 患の診断はもとより, 卵胞の発育, 排卵, 黄体形成の経 過を詳細值接追求することができる利点のあることは 今さらいうまでもないことである.

しかし，この「切り札」ともい光る方法が普及した反 面, さらに補助的にいらいろな臨床検查所見を検討して

\footnotetext{
* 東京振工大学農学部
}

みるという面が扮ろそかにされた嫌いがある。ささらに， 直晹検查法の上5に形態学的所見にもとづくものは, 検 查器官の形態々機能とに相関度の強い現象については検 查価值も高いのであるが，形態的变化は必ずしも機能的 変化と平行しているとは限らず，殊に病的状態に执いて このような場合が生じやすいものである.

それゆ兄に，直腸検查法汇頼り過ざることは時に盲点 を生むのであって，ホルモン作用の結果として現われる 種々の現象を多角的に観察検索し，それらの総合的所見 にもとづいてこれを支配しているホルモンの分泌機能を 察知する手段を講じなければならない。

\section{4. 繁殖機能の周期性}

雌の性周期については十分認識しているはずであるの に, いざ繁殖障害の診断治療となると周期を追って診察 することが案外閑却されている。例壳ば，卵胞囊腫など 一度の直腸検查で確認できるものもあり, 卵巣休止ある いは黄体遺残などは数日の間隔をおいて，再検査するこ とが望ましいことは常識となっている。しかしながら発 情が回帰する場合であると，もう発情期の所見を診るだ けに心を奪われてしまって黄体期に調べようとはしない ことが多い，発情期に和ける諸所見に異常はないかに注 目することはもとより重要なことであるが，周期性のあ る現象についてはその一時期に拈ける所見が正常である からといって機能が完全であるとは限らない，発情の前 後はもらろん, 周期を通じて正常な機能が営まれてはじ めて発情期に怙ける授精によって受胎する能力が備わる のであり，また授精が成立しても授精卵の着床維持など

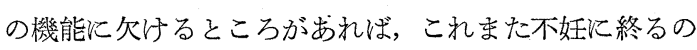
である。

この意味に招いて, 卵巣疾患の診療に当っては性周期 各期にわたる検索と，周期性に適応する性ホルモンの適 用が考党られねばならない。

\section{III性ホルモン作用の検查}

性ホルモンが生体内でぞのように㗢いているかを調べ るに当って, 最も基本的な検查は, 分泌器官, 血中およ び尿中に特けるその力価と消長を検定することである が, 現在の段階では広く臨床検查法として使用されるま でにいたっていない，従って，性ホルモンそのものを測 定することなく，その作用器官 (目標器官) に現われた 変化をもってその分泌が順調に営まれているかどうかを 検査する。 


\section{1. 性腺刺激ホルモン (G T H)}

下垂体前葉の分泌する性腺刺激ホルモンには (1) 卵胞 刺激ホルモン(F S H)，(2) 黄体形成ホルモン ( L H ), (3) 黄体刺激ホルモン $(\mathrm{LTH})$ の 3 種類がある.いずれ る雌沉招いては卵巣を目標器官とするが，L T Hはさら に乳腺の発育と泌乳関与している。これらのGTHは それぞれ独立したホルモンであるが，作用㳊当って相関 連して効果を発揮して扮り，またとの分泌は間脳一下垂 体系を介して卵胞ホルモン执よび黄体ホルモンによって 影響され, さらに光線その他神経系を介する諸種の刺激 によって影響を受けている。

F S H 拉よびL Hの分泌性周期伴う消長があり また両者のバランスは動物の種類によって異なるが，実 験動物で幼若なるのや下垂体摘出を行ったものについて 明らか炕された基本的な作用としては，F S Hは卵胞を 刺激しその発育を促すが単独では完全に成熟させるには いたらず，また卵胞ホルモンを分泌させる力はもたない が，L Hはこれに協力して卵胞を完全に成熟させ卵胞木 ルモンの分泌を促し，さらに卵胞の破裂一排卵を招き， 卵胞壁の获膜細胞の黄体化をきたす作用がある。そして 黄体の維持拈よび黄体ホルモンの分泌には L T Hが必要 であるといわれている，正常な成体浡いてはこれら 3 種それぞれ単独な作用が別個に出現するのではなく，一 連の協力した作用として発現している.

卵巣の機能異常はこれら 3 種のG T Hの分泌異常によ るのであるが， 3 種のうちどれがぞの位不足あるいは過 剩であるかを診定することは容易でない，主として直腸 検査に上り, 卵栄の大きさ, 卵胞の発育, 排卵の成否, 黄 体形成などの畉栄所見にもとづいてその䞶勢を察知する が，G T Hの作用を受けて卵栄から分泌される卵胞ホル モン拈よび黄体ホルモンが，その目標器官である子宮, 子宮頸管，腟などにどの程度の変化を招来しているか，

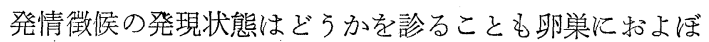
す GTH作用の判定の参考となる。

前葉の F S H 就よび L H の絶対的不足の場合は, 卵巣 の発育不全，機能休止，菱縮などを招来し，この場合は 副生殖器の発育不全, 萎縮を伴うことがあり, 無発情 で, 頸管粘液の周期的な性状変化は全くみられない。

F S H叔よびLHの分泌があってもまだ不十分な場合 には, 卵栄は不完全ながら機能を営むから, 直腸検查飞 よって卵胞の発育が認められるが，完全な成熟，排卵化 いたらず，卵胞は発育途中で萎縮退行するかあるいは閉 鎖黄体化する.この際, 発情は招招む称微弱であり, 頸 管粘液性状には若干周期的変化が認められるが定型的な 所見はまず現われない，これらの各所見を総合してGT Hの不足の程度を推定する。

主としてLHの不足によるとされるものには排卯遅 延, 卵胞囊腫がある。排卵遅延の場合は，F S H $\overline{\text { は完全 }}$
に充足されているとはいいきれないが，一応卵胞を発育 させるに足る量の分泌はあると認められ，LHも F S H に協力して卵胞を成熟させ卵胞ホルモン抢よび黄体ホル モンを分泌させるだけの分泌は営まれて扔り，発情を招 き頸管粘液にも発情期変化を起しているのであるが，排 卵を菱起するのに必要な F S H と L Hの量的関係が成立 するのに正常な経過より以上の時間を要しているわ沙で ある. 排卵遅延は持続性発情を伴 性発情の場合汇最終的渄卵するとは限らず無排畉に終 るものも少くない，この場合卵胞は拈拈むね閉鎖黄体化 する.

無排卵性発情は微弱発情の場合にる認められるが，正 常な発情経過をとるものの中にもまれに無排卵一卵胞の 閉鎖黄体化の経過をとるものがあるから，いわゆる低受 胎牛においては一応排卵の成否を確認する必要がある。

卵胞囊腫に扔いては，GTHの失調はさらに過度で, 前葉の F S H の過㮃または分泌機能の六進, L H 力価の 相対的不足をきたして招り，思牡狂を呈するものは卵胞 ホルモンの過剩状態を起している。

黄体遺残（永久黄体）の存在する場合は，新たな卵胞 の発育が起らないことは F S Hの不足状態沙るとみな されるが，一方黄体自身正常な退行の経過を巡らず，依 然として存続し黄体ホルモンの分泌を続けていること が，黄体の触診並びに副生殖器に現われている变化から して推定できる。これは L HないしはL T Hの分泌が消 退することなく持続しているためと解され，この原因の 多くは子宮内に異物が存在するなど, あたかも妊娠が成 立した場合に，妊娠黄体が維持されるのと同じようなメ カニズムでもって，黄体が維持されていると考学られ る.

\section{2. 卵胞ホルモン和よび黄体ホルモン}

両ホルモンの生産部位である, 卵栄拉よび作用する目 標器官に拈ける变化を指標として検査する。

卵栄に扔ける正常な性ホルモン分泌は，正常な卵胞お よび黄体の出現に伴っているが，卵胞抒よび黄体の触診 だけではそれらのホルモン分泌機能の失調を診定するこ とは難かしい。

子宮の触診は, その大きさ, 壁の厚さ, 緊張度, 収縮 力，その他の点でかなり参考になる所見が得られる。 子 宮内膜のバイオプシーによる組織学的検査は, 研究方法 としてよい方法であるが，ぞこででもやれるというもの ではない。

発情徴候の観察は両ホルモンの作用がよくわかる最も 便宜な方法であり，この際子宮頸管粘液性状について も，検索を加觉ることより微妙な作用状態を察知でき る.

頸管粘液性状は，卵胞ホルモン拉よび黄体ホルモンの

日獣会誌 12 (1959) 
影響を受けて鋭敏な反応を示すので，その性状変化から 逆に体内の両ホルモンの消長を察知できる.

卵胞ホルモンの作用によって頸管粘液は増量し，透明 となり，粘稠度は低下し，けんるい性が高まり，塗抹標 本に和いて顕著な樹枝状とも羊歯状とも形容できる結晶 形が出現し，精子受容性が高まってくる。 また黄体ホル モンはその粘稠度を高め，粘着性を增し，定型的な結晶 形成の発現を抑え，精子受容性を低下するなどの性状変 化を起す.

頸管粘液におけるこれら性状变化の度合によって，卵 胞ホルモンおよび黄体ホルモン作用の程度が判定され る。発情期に扣いて粘液の量, 粘稠度, けえるい性など は正常な発情粘液の所見を呈していても，結晶形成現象 および精子受容性は定型的な発情期像を呈していないも のがあり，乙かもこのような例に掠いては，定型的出現 を示す例よりも受胎率が低いことがわかっているので， 外観的な発情徴候や頸管粘液の肉眼的所見に異常は認め られないが，受胎が困難であるといういわゆる低受胎牛 や，その他卵巣機能の検索に当っては，結晶形，精子受 容性についてる検査することが望をしい.

また，黄体期に拈いて卵胞の異常発育，黄体機能不全 などがあるような場合には，頸管粘液性状にすぐ反映し てくるので，発情期沈いて授精に適する状態であるか 否かを知るだけでなく，性周期を通じて各期に㧍ける卵 胞ホルモン括よび黄体ホルモンの支配が順調に営まれて いるかどらかを知る手がかりとなる。

\section{III. 性ホルモン剤の使い方}

\section{1. 性腺刺激ホルモン剂}

性腺刺激ホルモン郕は，下垂体前葉とのものから抽出 したGTHの製剤はなく，妊婦尿中に排出される䋐毛性 性腺刺激ホルモン（HC G）执よび妊馬の血液中に含ま れている妊馬血清性性腺刺激ホルモン（PMS）の製㓮 である。市販製品の中には，HCGと下垂体 GTHを混 合したものもあるが，汪とんどが H C GまたはPMS製 剤で，最近この両者を混合したものが出ている。

HCG 拈よびPMSは前葉性の G T H と分泌源を異に するだけでなく，化学的にも別な物質である，別である とはいっても全く異質なものではなく似通った構造をも ち，生理作用も極めて類似している.

H C Gは下垂体を摘出した動物には反応を起し得ない 点が前葉性 $\mathrm{G} T \mathrm{~T}$ と大きく異なっているが，正常な動物 に与えるときはその下垂体を刺激して前葉のG T Hの放 出を促し，結果として前葉性GTHを与えたと同様な反 応が現われる，その際LH様作用がより強くみられるの で，HC G製剤は主としてLH不足と認められる場合に 使用される。

一方，PMSはもしろF S H様作用を主とするので，
F S Hを補うための使用に適している。

\section{（1）卵巣発育不全，休止，萎縮に対する応用}

臨床応用に当っては，その患畜自体の下垂体前葉の $\mathrm{G}$ $\mathrm{TH}$ 分泌機能に失調があるとされる場合に適用され，ま ず卵栄の発育を促し，卵胞の発育を刺激するため P M S 製剤が応用されるわけであるが，PMS製剤がまだ市販 されない頃は専ら $\mathrm{HC} \mathrm{G}$ 製剂が使用された。しかし， $\mathrm{H}$ C GよりはPMS，さらに両者の併用がより合理的であ るとい方る。併用垱ってはPMS 1, 000 2,000 IU(国

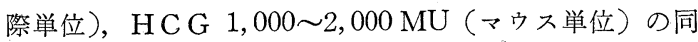
時注射末たはPMS 注射後卵胞の発育を確かめ，その確 認と同時に H C G 500〜2,000 MU の筋注(または静注) が行われる: この際使用の $\mathrm{HC} \mathrm{G}$ 製剤は水溶性のものを 使用するが，HC G 単用の場合には油性 2,000 MUを筋 注し，反応が現われなければさらに反復し，発情が開始 されたならば水溶性 $\mathrm{HCG}$ 1, $000 \mathrm{MU}$ の皮下注射を行 らとよいといわれている。

(2)，卵胞発育不全（無排卵），排卯遅延に対する応用 卵胞発育不全に扮いては，F S H の不足は前項の症例 に拉将るり軽度であると推測され，微弱ながら発情を 現わすので，低用量のPMS と中等量のHC Gを併用し 同時注射よりは分割注射法 (いわゆる one-two cyclic gonadotropin therapy) が合理的ともいわれる。この際 PMSの適用はいつでもよいというものではなく，自体 の卵胞発育に協力するよう予定発情の数日前に，黄体は 退行してきていることを確かめ，500～1, 000 IU を 1 回 または 2 回注射（連日または隔日）し，発情が開始し卵 胞の発育が確認されたならば直らに H C G $1,000 〜 2,000$ MUを追注する．施用に際して直腸検査とともに頸管粘 液性状の検査を行い，卵胞ホルモン作用に現われた効果 を調べながら，PMS执よびH C Gの適用量拉よび時期 を判断し，かつ授精の適期を判定するとよい.

卵胞は一応発育し発情を現わすが，発育卵胞が長く， 時には次々と交代して存続し持続性発情を呈するもの は，最終的には排卵する排卵遅延のものと，結局無排卵 で閉鎖黄体化するものとある。このホルモン療法として は，(i) 卵胞期（発情開始直前または開始後）にHC G 1, 000 2, $000 \mathrm{MU}$ (水溶液) の皮下注射，（ii）発情開始 後HC G 500 1,000 MU の静注，（iii）同じく PMS $500 \mathrm{IU}$ の静注，などによりそれぞれおよそ 24 時間以内 に排卵を招くことができる。

また，排卵遅延，無排卵に対して黄体ホルモン 5〜10 $\mathrm{mg}$ を発情開始後数時間以内に筋注する方法も行われて いる.この奏効機序については, 黄体ホルモンは前葉の L H放出を促吉作用があるためではないかといわれてい る。卵胞ホルモン（E）执よび黄体ホルモン (P) の前 葉GTH分泌に拉よぼす影響として，この作用は間脳一 下垂体系を介するものであるが，EはF S Hの分泌を抑 
制しLHの分泌を催進し，PはLHの分泌を抑制するが 積極的に F S Hの分泌を促すことはないといわれてい

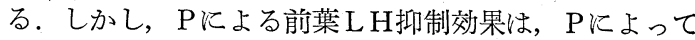
L Hの放出が促されその生産が追いつけないため一時的 飞L H 不足状態を生ずる結果が，Pによる L H分泌の抑 制とみられているのではないかとの意見もある。

\section{(3) 卵胞囊腫に対する応用}

卵胞囊腫のホルモン治療としては, 従来より $\mathrm{HCG}$ 製 剤の適用で, 排畉誘起, 黄体化が図られて和り, PMS 製剤の高単位を適用して一時的に多数の卵胞の発育を促 し，囊腫化した卵胞もともに排卵させようとするる方法 もあり，また思牡狂のものは卵胞ホルモン過剩状態にあ るので, 補助的㳻体ホルモンの大量を与兄て拮抗させ るととむに，GTH分泌の整調化を促すよ5 HC G 製剤 と併用することも行われる。

HC G 拈よびPMS製剤の応用についてはすでに多数 の報告例があり，それぞれ単独使用で效果を上げて招り $\mathrm{HC}$ G製剤は水溶性 $10,000 \mathrm{MU}$ の 1 回注射, 不治のも のには反復することによって良好な成績が得られて打 り, 油性 5,000 10,000 IU 子使用されている. 多囊胞 性の畉胞囊腫に対しては同様な処置の外，PMS製剂と の併用が試みられている。 PMS 1,000 2,000 IU と H C G 2,000 MUを同時併用するのであるが，な扔検討 の余地がある。

一般に，ホルモン療法の傾向としてある1種類の単独 使用から，併用あるいは混合使用の形がとられつつあ る。これは生体内のホルモン支配の面からも合理的なこ とであるが，応用に当って症例化適応した併用がなされ なければ意味がない，それぞれ力価検定法の異なるもの を数学的に足し合せたり，比率を上げてみてもそのまま 併用されるホルモンの総合作用力が算出されるものでは ない.

\section{2. 卵胞ホルモンおよび黄体ホルモン製剤}

卵胞ホルモン作用のある製剂として天然の卵胞ホルモ ン拉よびその合成品と，化学構造がそれらと全く異なる 合成発情物質がある，黄体ホルモン製剤はすべて合成さ れた黄体ホルモンの製剤である。

これらの応用は卵巣の機能を直接刺激するためではな く, 専ら卵胞ホルモン招よび黄体ホルモンの分泌不足 や，両者の量的関係の失宜を是正する目的をるっ使用 されるが，間脳一下垂体系を介する卵巣への「はねか党 り現象」を応用する適用法るある。

\section{（1）鈍性発情に対する応用}

卵胞成熟，排卵は周期的汇行われるが，発情徵候を伴 わないか，あるいはその発現が不明瞭なため授精の適期 を判定し難いが，直腸検查によって卵胞の成熟の度合を 確認し適期滛精を行えば受胎は可能であるので，G T Hの卵巣刺激作用は注ぼ順調営まれているが，卵胞木
ルモン拉よび黄体ホルモンの分泌，殊同者のバランス に失宜があって，発情徴候の発現に変調をきたしている と思われる，また，頸管粘液性状は発情期変化を現わす がその発現の低調なものが多い。

治療としては，卵胞ホルモン製剂拉よび黄体ホルモン 製剤が応用され，合成発情物質製剤 $5 \sim 10 \mathrm{mg}(10 \sim 20$ 万 IU）を予定発情日の $2 \sim 3$ 日前に注射して效果が認めら れるが，最近は合成発情物質 $5 \mathrm{mg}$ と黄体ホルモン $10 \mathrm{mg}$ の割で混合した油溶液が使用され良好な成績を上げてい る.

\section{（2）授精卵着床障害に対する応用}

いわゆる低受胎牛 (repeat-breeder) の成因の 1 つとし て, 授精卵の着床障害, 胎子の早期死亡にもとづくと認 められることが挙げられている. この処置として, 黄体 ホルモンの適用により子宮粘膜の着床的変化を完全に し，受胎成立維持のメカニズムを正常化する目的をるっ て，排卵後黄体開花期炕いたるまでに黄体ホルモン 30 $100 \mathrm{mg}$ の筋注が行われ，かなりよい成績が得られてい る.

（3）な打，無発情牛汇対し卵胞ホルモン製剤を投与し て発情を誘発し受胎させることができたとの報告もある が，一般卵巣機能不全にもとづく無発情牛注対して単 に発情だけ誘発しても, 卵胞の発育, 成熟拉よび排卵が 伴わなければ意味がないのであって，エストロゲンの大 量または連続注射は，却って正常な卵胞発育が障害され， るので濫用は慎まねげならない。

\section{IV．性ホルモン剤使用以前の問題}

繁殖障害のホルモン治療に当り，ホルモン剤を与兄れ ば直ちに受胎が期待されるとの過大な效果を望むことは 無理である、性ホルモンは受胎の成立に必要な生体のコ ンディションを整える因子であって，娃陙ホルモンとい らようなものではない，治療の結果依然として不妊であ ったということは治療の目的を達しなかったことであっ ても，直ちにホルモンが效かなかったといらことと同じ であるとは限らない，ホルモン剤を適用し最終的に受胎 を成立させるため沈，その適用以前のいろいろな間題 がある。

\section{1. 生体の感受性}

性ホルモン剤を適用された動物が果してそれに反応し 得る態勢にあるかどうか，まずその感受性を整えてやる 必要がある。々かく繁殖障害は直接生命淿かかわる症状 を呈しないので，運動の不足あるい膼度の使役，栄養 の不足あるいは偏向などの障害, 肝機能の障害などがあ るのにかかわらず，いきなり性ホルモン鼡に頼る傾向が あるのは感心したことでない。

肝臟は性ホルモン殊に卵胞ホルモン抢よび黄体ホルモ ンの不活性化を通じて，体内のホルモンバランスを整え

日獣会誌 12 (1959) 
るのに重要な役割を果しているので，この機能の障害は 性機能障害を起す一因となっている，この意味で，肝蛭 などによる障害を駆除し，グルクロン酸，メチオニンな ぞをあらかじめ投与するとか，ホルモン治療と併用して 肝機能の調整を図ることは效果が大きい.

ある種のビタミンおよびミネラルの補給も全般的な生 理的条件を整える上に有効であるが，それが直ちに繁殖 障害の原因，治療と結び付くものであるかは不明の点が 多い.

\section{（2）性ホルモン以外のホルモン}

副腎皮質は, 糖類, 塩類㐨よび水分の代謝に関係深い 皮質ホルモン作用を介し繁殖機能にも重大な関係をもっ ている。この意味でストレスを除き副腎皮質機能の正調
を図ることは必要であるが，まだ繁殖障害治療に詨する $\mathrm{ACTH}$ 和よび皮質ホルモン製剤の適用について確立し た治療法はない。

甲状腺ホルモンも体内の新陳代謝機能支配の面および 性ホルモンとの相互作用の点で無関係ではあり得ない が，繁殖障害との関係についてはまだ不明の点が多く， その治療に使われるにいたっていない。

以上，雌牛の卵巣疾患注対する性ホルモン療法につい ての基本的な考え方を中心として記したが，図表，写真 などを省き專ら記述に頼ったので, 生硬難解の点は他の 解説書を参考にしていただきたい。な拉，ホルモン郕の 使用法については公的数的な例を挙げたのであって，こ れ以外の適用方法を閑却視するものではないことを念の ため付言して和く.

\section{[地方会便り]}

\section{（東京）臨床技術研修会開催さる}

7 月 29 日午後 6 時, 東大農学部家畜病院にて, 曰井和 哉助教授指導の下に第 1 回を開いた。熱心な参加者は 40 名に抽よび「骨折の治癒に関する要点」の講演を聴いた 後, あらかじめ準備された実験犬 10 頭を各班每に分担, $22 \mathrm{~A}$ 鋼による骨折処置を微に入り細をうがった日井助教 授の懇切な指導の下に, 各自が納得のいく研修をし, 得 るところが多かった。

\section{ブラジル移住獣医師よりの第 1 . 信}

会誌第 7 号に所載の石部氏より 7 月 27 日附で便りがあ った. 現在サンパウ口市から約 2 時間かかる山中で農業 を営又ながら 1 年間位ブラジル事情の勉強をする予定と か, 日中は $27 \sim 8^{\circ} \mathrm{C}$, 朝夕は $12 \sim 20^{\circ} \mathrm{C}$ で現在ブラジルで は冬型なのだそうだ。またサンパウロ市では犬るなかな か盛んで展覧会には400〜 500頭位の出陳もあると, シェ パードを飼っている日本人に会い，その目録なども見せ てもらった由. 因みに氏の住所は Y. IsHibe a/c Sr. H. GYOTOKU, RUA AMERICO BRASILIENSE 419, SAO PAULO, BRASIL.

\section{政治㤠談会開催さる}

かねて政治活動について，よりよい協議中のところ， 本会並びに東京都獣医師政治連盟と共催の下に推䳸議員 を打って一丸とせる都獣医師政治議員団を結成, その第 1 回の政治留談会を, 8 月 9 日一夕の宴を凉風誘 万不忍 池畔にもった. 当日第 6 号台風の飛入り参加があったに もかかわらず, 議員団側は黒川参議院議員をはじめ, 都 議会議員 6 名, 区議会議員 4 名, 石川右三郎議員 団顧 問, 本会側は大越会長以下 12 名, 政連側は市川委員長以 下11名, 計35名にのぼる出席を見, 定刻山田副委員長司 会の下に開会, 胸襟を開いて相語らうこと 3 時間に执よ び，会の悩みを行政面での打開と解決の実現に相提携し て協力邁進, さらに社会福祉の增進と業界の発展を期待 しつつ予期以上の成果を打さめて閉会した。

\section{P.R 活動について}

芸術映画社企画製作中の動物シリ一ズ文化映画「ネ コ」について本会は積極的に協力しあるいは製作上の参 考意見や資料を提供しているが，7月21日は東大農学部
の家畜外科室で「ネコ」の手術を撮影，これに必要なる 「ネコ」を斡旋したこの映画が, より多く獣医業界のた めに役立つことを期待する。 (岡田博亘記)

（大阪）会員招よび家族同伴のリクレーションの催し

本会設立十周年の記念事業の一つとして7月19日比跖 山ドライブウェーを兼社京都拈よび滋賀方面の名勝を探 る観光バスによるリクレーションを会員および家族を招 待して実施したが. (参加者総員 235 名)

各班はそれぞれ所定時刻に集合場所に集り日本交通の 72 人乗観光バスに乗車午前 9 時バス 4 台は守口市に集結 し, 車を連衫て一路淀川沿いの京阪国道を北汇進久沿線 の名勝旧蹟のバスガール嫹の美声案内よろしく, 京都東 寺, 東本願寺, 平安神宮に参抨 (当日はちょうど日本三 大祭の一つである祇園祭りの日であったため市内はなか なかの賑いである) を終党, 山科逢阪山を越兄て午前 11 時30分懇親会場の大津三井寺山内円満院門跡に到着 し た。（当院は今から970年ほど前，村上天堭の第三の皇子 悟円親王の開基で，歴代門主は皇子皇孫によって継承せ られ宸殿は応挙の名画による重要文化財, 昭和 9 年文部 省より名勝史蹟に指定された名さつである)

会場は同院庫裡 100 畳敷の大広間で同院献立ての精進 料理の数々, 榎原会長の挨拶, 謝辞のあった後, 和気満 堂瑟談の5ちに昼食を終光院前で記念写真を撮り午後 1 時出発比頕山ドライブウェーに向 5 . 山上根本中堂にい たる坦々たる有料舗装道路の快走, 右方眼下に展開する 琵琶湖, 大津の全景, 遠く東江州の近江富士その他の山 々を一望に収め得る絶景，山頂にいたるに従い寒冷線を さまよう心気して，参加者のすべては心行くまで快適な ドライブウェーを味った模様であった。駐車し根本中堂 に参詣時その他随所に参加会員中新婚早々の熱い型，小 供を両手の家族円満型， 卆老父母の手をひく孝養型な どさまざまそれぞれ携行の写真機でパチパチとすべては 実に楽しそ5。

根本中堂より車は近江神宮を経て大津市を過ぎ石山寺 に到着寺内を参詣し紫式部の古蹟を偲んで小唕の後帰路 につき，午前各班の集合場所にそれぞれ到着解散したの は午後 8 時過ぎであった。幸いにも終日好天に恵まれ本 会設立以来はじめての会員括よび家族相互の融和懇親を 企図する本行事も，十分との目的を達し得た意義深い行 楽の一日を終えることができた。

(榎原義一記) 